\title{
HISTORY OF MEDICINE SECTION
}

There is no journal published in this country which deals with the history of medicine, and the Editor feels that this important subject has been greatly neglected in the teaching of medicine both to students and to post-graduates. We shall, therefore, be publishing in these pages from time to time, interesting articles linking the past with the present, and it is to be hoped that it will become a very popular section of the Journal.

\section{EDITOR}

\section{JUBILEE OF THE DISCOVERY OF X-RAYS}

$$
\text { BY W. R. BETT, M.R.C.S., L.R.C.P., F.R.S.L. }
$$

The recent commemoration in London of the 5oth anniversary of Röntgen's discovery of the $\mathrm{X}$-rays was memorable for several reasons. That in these culturally and gastronomically unpropitious times distinguished scientists from all parts of the country and even from abroad, representing many professions and many interests, should have united in pious observation of an event only fifty years old-traditionally the commemorative instinct of mankind is stirred only at the turn of a complete century-bestows upon this event a unique prestige. Curiously enough the jubilee of the birth of radiology coincided with the centenary of the birth of its father.

The tale of the discovery of the Röntgen-rays is familiar, but does not age through re-telling. The accidental element in the discovery has been over-emphasised. Just over 50 years ago, late in the evening of November 8, I895, the tall, dark-bearded University Professor of Physics in the little Bavarian town of Würzburg, Wilhelm Konrad Röntgen, experimenting in his darkened laboratory with the passage of a high-tension current through a Crookes tube, was startled and intrigued by the mysterious, brilliant fluorescence of some barium platina-cyanide crystals which happened to be lying on his work-bench. The Crookes tube was encased in a black cardboard screen, opaque to all known rays, and yet something had passed through that opaque screen. Would this something pass through objects thicker than cardboard? Röntgen's curiosity was aroused. Various metals were interposed between the vacuum-tube and the platino-cyanide in the path of the rays which soon were to immortalise his name. Introducing his hand, the shadow of his bones greeted his astonished eyes, and he was quick to appreciate that substitution of a photo- graphic plate for the platino-cyanide screen would produce a permanent "shadowgraph" of the inside of the human body. A happy accident, then, leading to the discovery of what Röntgen modestly named the "X-rays." Yet it is salutary to remember that this very same accidental observation must have been made previously by other scientists. Sir William Crookes, for example, used to complain of the fogging of photographic plates in the neighbourhood of a Crookes tube in action The discovery of the X-rays depended upon the reaction of Röntgen's mind to this accidenta observation, for which it may or may not have been prepared at that particular moment.

Copies of Röntgen's first paper, "Uber eine neue Art von Strahlen," presented to the Würzburg Physico-Medical Society on December 28, I895, reached London early in January, 1896, when the news was cabled to the world. Unlike the majority of discoveries made in the academic seclusion of a laboratory, its practical possibilities appealed to the imagination of man at once. Literally within a matter of days its application to medicine had been confirmed by scientists who repeated Röntgen's experiments with eagerness, delight, and makeshift apparatus. The first X-ray photograph of a human hand (his own) in this country was taken by Campbell Swinton on January I6th. On February 7 th C. T. Holland discovered by the use of X-rays a bullet in a boy's hand. The devoted and enthusiastic researches of many British pioneers led to their disablement and even death.

Except from puritanical womanhood, the practical application of Röntgen's discovery did not provoke the vociferous opposition which greeted the ideas of Pasteur and of Lister. Scientists and the public alike were impatient for its full utilisation 
and exploitation. A London firm offered for sale "X-ray proof under-clothing for ladies," while an American advertised the transmutation of base metals into gold!

The fame and notoriety which overwhelmed the discoverer in the 5 Ist year of his age failed utterly to spoil him. He remains to this day one of the most sympathetic figures in the history of scientific endeavour. Refusing the offer of a title from the Prince Regent of Bavaria, he accepted the Nobel Prize for Physics in the first year of its award.

The fact that to-day every hospital worthy of the name has a well-equipped X-ray department may be said to constitute Röntgen's greatest monument.

Medical men are apt to forget that apart from medicine Röntgen has left his signature on all physical studies. He himself was the first to take an X-ray photograph of a piece of metal. Industry promptly became X-ray minded. In a larger sense the discovery of the $\mathrm{X}$-rays laid bare some of the physical secrets of nature, thus enabling far-seeing scientists to explore the hitherto forbidden world of the atom and to liberate atomic energy.

As a commemorative tribute to Röntgen's discovery an ambitious and fascinating programme had been arranged by various learned societies and scientific institutions. At the Royal Institution Dr. A. Muller, Assistant Director of the Davy Faraday Laboratory, on November 6th, gave a lecture-demonstration, illustrated with unique historical exhibits, on the background of Röntgen's discovery, paying a tribute to Michael Faraday who had laid the foundation with his experiments on electrical discharge in gases. The following evening the B.B.C. staged a dramatic account of the story of the X-rays from their discovery to the present. At the Royal Society a commemorative conference was opened on November 8th. by Sir Henry Dale and addressed by, among others, Sir Lawrence Bragg, who also spoke the following afternoon at the Phoenix Theatre in Charing Cross Road on "The scientific consequences of Röntgen's discovery." The Radiology Section of the Royal Society of Medicine, under the chairmanship of Lord Horder, was addressed on the afternoon of November 8 th by Dr. R. E. Roberts, Dr. James Brailsford, Professor F. L. Hopwood, and Mr. Cuthbert Andrews. This was followed by an evening reception. On November roth Mr. H. T. Ferrier spoke on "Postgraduate education in medical radiography" before the Institution of Electrical Engineers. The Royal College of Surgeons held an evening meeting on the 9th with addresses by Professor Sidney Russ on the dangers associated with the use of X-rays, and by Professor H. J. Muller of Amherst College, Massachusetts, on genetic effects in relation to X-rays and other ionizing radiations.

A small but interesting exhibition of historical apparatus and books had been arranged at the British Institute of Radiology. This included two of the first books on X-rays published in this country in r896: A. B. Chatwood's The New Photography, and H. S. Ward's Practical Radiography: A Handbook on the Application of the $X$-Rays.

\section{NEW PUBLICATIONS}

\section{"THE DEVELOPMENT OF INHALATION ANAESTHESIA" I846-I900}

The Wellcome Historical Medical Museum has arranged to publish, in conjunction with the Oxford University Press, an important work on The Development of Inhalation Anaesthesia from I846 to Igoo, by Dr. Barbara M. Duncum, of the Nuffield Department of Anaesthetics, University of Oxford, and formerly on the staff of the Wellcome Historical Medical Museum.

The work is to be the first of the Museum's postwar series of Research Studies in the History of Medicine. It deals exhaustively with the history of inhalation anaesthesia in England, the United States of America and on the European Continent, from the scientific and clinical points of view, and shows, as well, the influence of general current events upon this branch of surgery. Most important features of the work are its investigation of the various changes of opinion in regard to the physiological action of anaesthetics, the evolution and practical application of inhalers and other apparatus and the introduction and adoption of anaesthetic drugs, during the period under review. This work, which is illustrated by over I6o photographs and drawings, should prove of especial interest to the student of medical history, and, since it shows how modern anaesthetic methods have grown from nineteenth-century beginnings, should be of great practical value to anaesthetists and research workers in anaesthetics. 